\title{
Zkušenost s halucinogenní rostlinou ayahuasca v kontextu šamanského rituálu
}

\author{
Veronika Kavenská - Hana Simonová \\ Katedra psychologie, Filozofická fakulta Univerzity Palackého v Olomouci, Vodární 6, Olomouc, 77900.
}

Do redakce doručeno 4. února 2014; k publikaci přijato 15. května 2014

\section{EXPERIENCE WITH HALLUCINOGENIC PLANT AYAHUASCA IN THE CONTEXT OF SHAMANIC RITUAL}

\begin{abstract}
This research focuses on people who travelled to the Amazonian forests to experience natural hallucinogen Ayahuasca in the context of "shaman" rituals. Anthropologists began describing this phenomenon in the 1970s as so called "shaman tourism" and it is becoming more and more recognised as such by citizens of countries across Europe and USA. Our goal was to map how the Ayahuasca shaman tourism functions - what motivates the people who seek this type of experience. The benefits, risks and the consequent integration of this extraordinary experience on their lives. Data was collected in the Czech Republic and in the Peruvian Amazon in the places which are known as the centers of ayahuasca shamanic tourism (Tarapoto, Iquitos) through a process of semi - structured interviews, screening questionnaires and involved observation. We obtained testimonies from seventy seven people. The interviews show that the main motivation to use Ayahuasca was curiosity, a form of therapy for mental health problems and the need for self - knowledge. Benefits were seen primarily in relation toward self, in terms of self - knowledge and self-acceptance, and on the spiritual, mental, somatic and relational levels. A detached viewpoint of life, satisfaction and clarification of one's life were also mentioned quite often. Among the stated risks were the distrust of the shaman or organizer. The distortion of information they provided and the exposure to a high - risk situation. Most respondents regard the experience itself as a safe one. Any difficulties experienced with taking Ayahuasca were later evaluated as positive in terms of life improvement. This research was funded by two research projects at Palacký University in Olomouc: IGA (SPP:432101021) and FPVČ (SPP: 452100061).
\end{abstract}

KEY WORDS Ayahuasca; shaman tourism; shamanism; ritual; Amazon Basin

ABSTRAKT Výzkum je zaměřen na osoby, které se vydaly do amazonských pralesů užívat prírodní halucinogen ayahuasku v kontextu „šamanského“ rituálu. Tento jev popisovaný antropology od 70. let. 20. stol. jako tzv. „šamanský turismus“ je stále aktuálnější především mezi obyvateli zemí Evropy a USA. Našim cílem bylo zmapovat, jakým způsobem ayahuaskový šamanský turismus probíhá - motivaci osob, které tento druh zkušenosti vyhledávají, př́nosy, rizika a následnou integraci této neobvyklé zkušenosti. Sběr dat probíhal v ČR a v peruánské Amazonii na místech známých jako centra ayahuaskového šamanského turismu (města Tarapoto a Iquitos) formou polostrukturovaných rozhovorů, screeningových dotazníků a zúčastněného pozorování. Získali jsme výpovědi 77 osob, které mají zkušenost s ayahuaskou v kontextu rituálu v pralesech Jižní Ameriky, především pak v Peru. Z rozhovorů vyplývá, že hlavní motivací pro užití ayahuasky byla zvědavost a touha po dobrodružství, léčba psychických problémů, potřeba sebepoznání, zájem o psychedelickou medicínu a terapii, spirituální rozvoj a nalezení životního směru. Př́nosy byly vnímány především ve vztahu k sobě ve smyslu sebepoznání a sebepřijetí a v rovině duchovní, psychické, somatické a vztahové. Často byl zmiňován životní nadhled, spokojenost a ujasnění si životního směřování. Jako rizika byla uváděna nedůvěra v šamana či organizátora, zkreslení jimi poskytnutých informací a vystavení rizikové situaci. Většina respondentů považuje samotnou zkušenost za bezpečnou a náročné prožitky během sezení s ayahuaskou byly následně hodnoceny kladně ve smyslu zkvalitnění života. Výzkum byl hrazen ze dvou výzkumných projektů UP: IGA (SPP:432101021) a FPVČ (SPP: 452100061).

KLÍČOVÁ SLOVA ayahuasca; šamanský turismus; rituál; Amazonie 


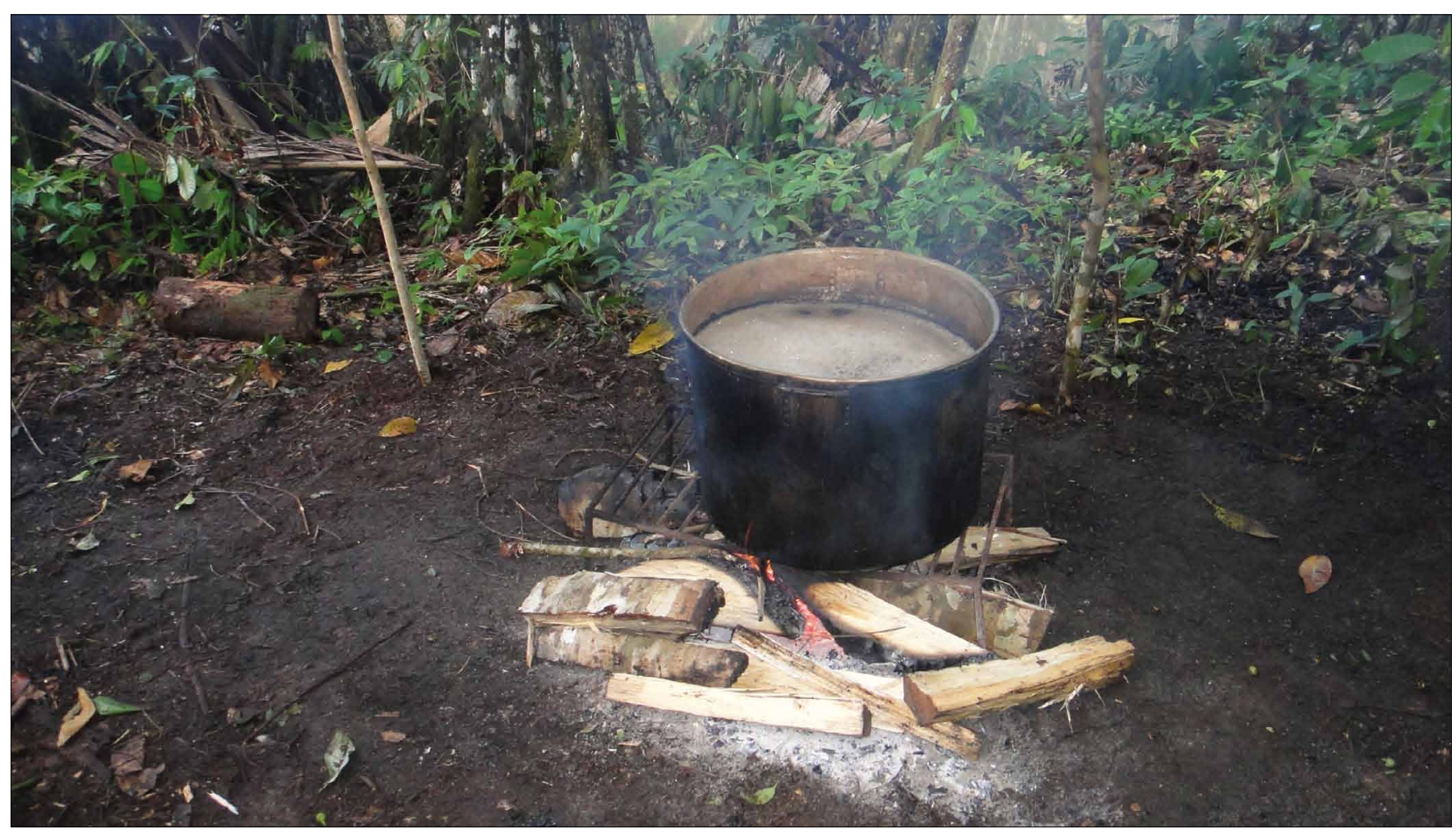

Obr. 1. Proces prípravy ayahuasky

\section{ÚVOD}

\section{„Liána smrti“" ayahuasca}

Ayahuasca je purgativní psychotropní odvar původně užívaný domorodými obyvateli jihoamerických pralesů Peru, Kolumbie, Ekvádoru a Brazílie mj. k léčivým, spirituálním a kulturním účelům (Dobkin de Rios, \& Grob 2005; Metzner 2006). Je součástí amazonské kultury již více než 8000 let a v dnešní době ji užívá nejméně 72 domorodých kmenů amazonské oblasti (Luna 2002). Slovo ayahuasca pochází z kečuanského slova „huasca“ což znamená „víno“ nebo „liána“ a „aya“ znamená „duše“, „mrtví lidé“, nebo „duchové“, v překladu tedy „liána smrti“, nebo „víno duchü“ (Metzner 2006). Ayahuasca je tradičně podávaná curanderem, neboli léčitelem, v kontextu šamanského rituálu, který má posvátný charakter (Dobkin de Rios 2009).

Ačkoli existují různé druhy rostlin, které se přidávají do odvaru ayahuasky v závislosti na konkrétních curanderos (léčitelích) a geografických oblastech (Mabit, Campos, \& Arce 1992), tradičně se připravuje kombinací dvou rostlin: dřevité liány Banisteriopsis caapi, nazývané ayahuasca, podle které je nápoj pojmenovaný, a z listů keře Psychotria viridis neboli chacruny. Banisteriopsis caapi obsahuje harmala alkaloidy, které působí jako inhibitory monoaminooxidázy a zpomalují štěpení psychoaktivní látky dimethyltriptamin (DMT), která je obsažena v Psychotria viridis (McKenna, Towers, \& Abbott 1984). Callaway et al. (1996) detekovali v krevní plazmě patnácti zdravých mužů (dobrovolníků) po rituálním požití aya- huasky alkaloidy harmin, harmalin, tetrahydroharmin (TTH) a N, Ndimethyltryptamin.

Ayahuasca se po vypití vstřebává do krevního oběhu a působí na centrální nervovou soustavu. Tím navozuje změněný stav vědomí typicky provázený barevnými zrakovými halucinacemi (Metzner 2006), zesílenou percepcí, zjemněnými sluchovými a čichovými vjemy, akcelerací mentálních funkcí a často také dochází $\mathrm{k}$ narušení racionálních ego obran. Tento stav lze přirovnat $\mathrm{k}$ vědomému snění. Expanze percepčního spektra umožňuje nahlížet na realitu z nových úhlo̊ pohledu a nalézání originálních řešení problémů (Mabit, \& Sieber 2006; Mabit 2002; Shanon 2002; Frecska, Móré, Vargha, \& Luna 2012).

Ayahuasca má trpkou hořkou chut’ a tmavé zbarvení. Je typicky podávaná $\mathrm{v}$ rámci nočních rituálů, aby se eliminovaly vizuální rozptyly a člověk se tak mohl soustředit na vnitřní vizionářské prožitky. Rituály provázejí zpěvy (ícara), které slouží ke stimulaci a udržení změněného stavu vědomí a jsou považovány za významné symbolické průvodce do ,jiných“ a „vnitřních“ světů. Účinky ayahuasky se projevují na třech úrovních: fyzické, psychické a spirituální (Mabit, \& Sieber 2006).

Účinky ayahuasky nastupují v průběhu 30 - 60 minut po jejím požití, vrcholí v intervalu 60 - 120 min a účinek vymizí po asi $2-4$ hod. Dochází mimo jiné ke zvýšení krevního tlaku, zvracení a k somaticky - dysforickým stavům (Riba et al. 2001). Na úrovni mozku byla zaznamenána signifikantní aktivace frontálních a paralimbických oblastí, zvýšený průtok krve $\mathrm{v}$ bilaterálních oblastech předního ostrovního laloku s vyšší intenzitou v pravé mozkové hemisféře a v levé amygdale, která je spojená s emotivními reakcemi (Riba et al. 


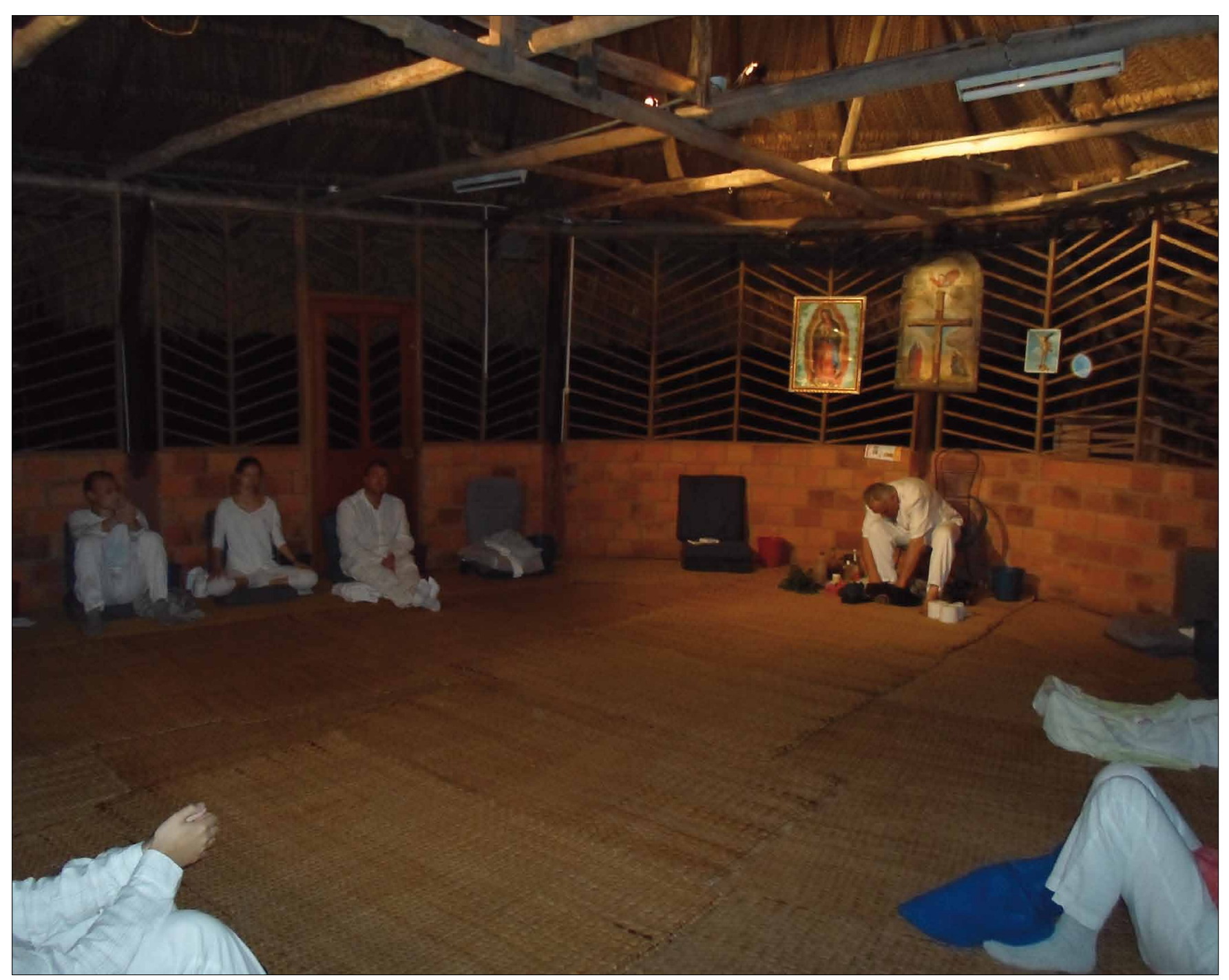

Obr. 2. Čekání na zahájení sezení s ayahuaskou

2006). Ayahuaskové halucinace či vize ${ }^{1}$ pramení z aktivace rozsáhlé neuronové sítě okcipitálních, temporálních a frontálních kortikálních oblastí, které jsou spojené s obrazotvorností, pamětí a exekutivními funkcemi (např. záměr a plánování). Intenzita opětovného vybavení obrazů odpovídá přirozeným dojmům či představám, což dává vnitřním prožitkům pocit reálnosti (de Araujo 2012).

Na psychické úrovni ayahuasca vyvolává změny ve vnímání, $\mathrm{v}$ prožívání a $\mathrm{v}$ procesu myšlení při současně zachovaném kontaktu s realitou. Myšlenky, vize a vzpomínky často nabývají emocionálního obsahu (Riba et al. 2001). Ayahuasca zprostředkovává př́stup do hlubokých vrstev nevědomí, prožitých traumat a vytěsněných vzpomínek (Mabit, Giove, \&Vega 1996). Z výzkumů vyplývá, že u osob, které poprvé užívaly ayahuasku v kontextu církve Santo Daime a União

1 pozn. autora: Osoby užívající ayahuasku často hovoří o vizích, nebot' vyvolaný změněný stav vědomí často provází různé vhledy a uvědomění. do Vegetal po dobu jednoho/dvou týdnů či šesti měsíců, se nejčastěji objevovala numinózní zkušenost, pocit smíření, vhled, ohrožující reakce, snížení fyzických bolestí a intenzity psychiatrických symptomů, zlepšení psychického zdraví, zvýšená sebedůvěra, optimismus, pocit nezávislosti, rozvoj asertivity, klidu a radosti (Barbosa, Giglio, \& Dalgalarrondo 2005; Barbosa, Cazorla, Giglio, \& Strassman 2009). Winkelman (2005) díky své studii s šestnácti osobami, které podnikly cestu z Evropy a Severní Ameriky do Amazonie za účelem užití ayahuasky, zjistil, že užívání ayahuasky mělo pozitivní vliv na zvýšení sebeuvědomění, osobní rozvoj, vhled do vlastního života, prrístup do hlubších dimenzí já a posilnění „vyššího jác. Někteří respondenti hodnotili pozitivně své spirituální zážitky, pocit osvícení a vyléčení emocionálních a fyzických problémů.

Bouso et al. (2012) v rámci své longitudinální studie zjistili, že uživatelé ayahuasky vykazují oproti kontrolní skupině vyšší závislost na odměně, vyšší sebe - transcendenci, nižší vyhýbání se nebezpečí a nižší sebe - zaměření. U uživatelů ayahuasky 
se neprokázalo zhoršení psychického zdraví nebo kognitivní poškození. Schmid, Jungaberle, \& Verres (2010) provedli studii s patnácti osobami, které podstoupili terapii s ayahuaskou pro své specifické choroby (chronická bolest, rakovina, astma, deprese, závislost na alkoholu a hepatitida typu C). Většina účastníků byla přesvědčena, že ayahuasca pozitivně ovlivnila jejich nemoc či zlepšila jejich copingové strategie vůči nemoci a zlepšila jejich celkovou životní spokojenost (well being).

$\mathrm{Na}$ spirituální úrovni, taktéž nazývané transcendentální, lze mluvit o zkušenostech „za hranicemi jedince“, které umožňují nový náhled do transcendentálních dimenzí a vedou ke smysluplnému životu, jsou doprovázené pocitem smíření se sebou samým, $\mathrm{s}$ druhými, $\mathrm{s}$ prírodou, $\mathrm{s}$ vesmírem a s bohem jakožto zdrojem hlubokého míru (Mabit 1988b, in Mabit, Giove, \& Vega 1996). Trichter (2006 - 7) sledoval vliv užívání ayahuasky na spirituální rozvoj osobnosti. Pracoval se dvěma skupinami osob v Kalifornii a v Kanadě, které se po dobu šesti měsíců účastnily ayahuaskových ceremonií s peruánskými šamany. Výsledky výzkumu ukazují, že u více než $75 \%$ účastníků vzrostl zájem o spirituální rozvoj. Jedinci, kteří prožili intenzivnější a pozitivnější spirituální zážitky, vykazovali větší a pozitivnější změny v dlouhodobém spirituálním „well being“. Dále byla identifikována běžná spirituální témata, např̀ prítomnost světla a geometrických obrazců, úcta, respekt či vděk, bázeň, pocit spojení, osobní reflexe, vhledy a posvátnost v termínech vy̌šsí síly nebo boha. Krippner a Sulla (2000) zjistili, že ve zprávách $\mathrm{z}$ ayahuaskových sezení lze najít spirituální obsahy a díky tomu přirovnávají ayahuasková sezení ke „spirituální psychoterapii“. Spirituálně založený psychoterapeut by tak mohl obsahy $\mathrm{z}$ ayahuaskového sezení využít při práci s klientem.

\section{Odlišné pohledy na ayahuasku}

Ayahuasca je domorodými lidmi považována za učitelskou rostlinu, která zprostředkovává komunikaci s živými bytostmi, energiemi či silami, se kterými po užití odvaru přicházejí do kontaktu a učí se od nich (Grunwell 1998). Obvykle je tradičně užívána $\mathrm{k}$ otevření dveří do tzv. „jiného světa“ a ke komunikaci s předky a dušemi zvírat (Mabit, \& Sieber 2006). Všechny posvátné halucinogeny umožňují proniknout do expanzivního, osvobozujícího vesmíru bohatého na informace, plného nekonečných možností dalších realit a budoucností. Neodvádí člověka od sebe samého, ale přibližují jej k hluboké podstatě svého já, osobního potenciálu a balanci skrze pravé sebe - uvědomění (Heaven, \& Charing 2006).

Ayahuasca se řadí mezi halucinogeny. Někteř́ autoři však tvrdí, že toto zařazení s sebou nese pejorativní zabarvení a pohrdavé postoje, nebot' $\mathrm{z}$ americko - evropského pohledu jsou změněné stavy vědomí vnímané jako negativní antisociální formy chování, vzbuzující strach a nedůvěru, které by měly být postihovány nebo $\mathrm{v}$ prípadě závislosti léčeny (Shanon 2002; Dobkin de Rios \& Grob 2005; Mabit, \& Sieber 2006). Antropologické záznamy užívání ayahuasky ukazují, že pokud vyvolané změněné stavy vědomí podléhají podmínkám zajišstujících bezpečné užití, jsou výsledky pozitivní a člověku prospěšné (Dobkin de Rios \& Grob 2005). S jasně vymezenými kulturně zakořeněnými záměry a skupinovým užíváním psychedelik $\mathrm{v}$ rámci posvátného rituálu vedoucímu $\mathrm{k}$ osobní zkušenosti, je riziko vzniku závislosti téměř nemožné. Proto se v tradičních společnostech problémy se závislostí objevují jen zřídka. Západní průmyslová společnost užívání psychedelik znesvětila ve smyslu vymizení rituálního posvátného užívání a integrace zkušenosti, což vedlo k rozvoji drogových závislostí a k patologizaci posvátných rostlin (Dobkin de Rios 2009; Mabit 2002).

Bouso et al. (2012) prováděli výzkum se 127 pravidelnými uživateli ayahuasky po dobu jednoho roku a zjistili, že pravidelné užívání ayahuasky nevykazuje známky návykovosti. Fábregas et al. (2010) zjistili, že uživatelé ayahuasky skórovali signifikantně níže v porovnání s kontrolní skupinou na "Addiction Severity Index Alcohol Use“ a „Psychiatric Status subscales“. Celkově se rituální užívání ayahuasky nezdá být spojené se škodlivými psychosociálními účinky typicky způsobované jinými návykovými látkami.

Ayahuasca je dokonce ve formě terapeuticky navozených změněných stavů vědomí užívána jako účinný prostředek pro léčbu drogově závislých (Mabit, \& Sieber 2006; McKenna 2004). Šamanské praktiky mj. navozují relaxaci, uvolnění stresu, dlouhodobé změny na úrovni metabolismu a neurotransmiterů v mozku a stimulují uvolnění endogenních opioidů a serotoninu, které navozují př́ijemné pocity (Winkelman 2001). Ze studie o rizicích orálního užívání DMT a harmala alkaloidů (Gable 2007) vyplývá, že užívání ayahuasky sebou nenese potenciál jejího zneužití, naopak, pokud je ayahuasca užívána $\mathrm{v}$ dobře zabezpečeném sociálním kontextu, jsou dokumentovány dlouhodobé psychologické prrínosy. Frecska, Móré, Vargha a Luna (2012) zjistili, že uživatelé ayahuasky vykazují vyšší míru kreativity. Otázkou je, zda užívání ayahuasky vede $\mathrm{k}$ rozvoji kreativity nebo zda kreativní lidé častěji vyhledávají nové zážitky, které zahrnují i ayahuaskové rituály. Peruánské ministerstvo zdravotnictví začalo uznávat široký potenciál domorodých šamanských léčitelů a Národní institut tradiční medicíny (INMETRA) podporuje výzkum v oblasti tradiční medicíny (Mabit, \& Sieber 2006). K přesnějšímu určení léčebného potenciálu ayahuasky jako medicíny je třeba jít za hranice konvečních modelů léčby a prozkoumat učení minulých a vzdálených kultur (Dobkin de Rios, \& Grob 2005). Pro moderní západní drogovou politiku, která je založená na racionální pozitivistické ontologii zastávající názor, že psychoaktivní substance jsou chemické podstaty a jejich efekty jsou pouze mechanické, přestavuje tato problematika výzvu (Tupper 2008).

\section{Užívání ayahuasky a zákony}

V současné době se tradičních ayahuaskových ceremonií ve velké míre účastní také lidé z Evropy a Severní Ameriky, kteři za tímto účelem navštěvují Amazonii, kde je užívání ayahuasky legální. Brazilská vláda v roce 1991 zhodnotila, že 
př́nosy rituálního užívání ayhauasky převažují nad potenciálními riziky a dala svolení k užívání „posvátného čaje“ skupinám, které se hlásí k církvi Santo Daime a União de Vegetal (Tupper 2008).

V dubnu 2008 bylo rituální užívání ayahuasky v rámci náboženských ceremonií uznáno za součást brazilského národního kulturního dědictví (Labate, \& Goldstein 2009) a v červenci 2008 vydal peruánský Národní institut prohlášení o legálním a chráněném užívání ayahuasky pro tradiční rituální účely a uznal její posvátný charakter. Zároveň se stanovila povinnost odlišovat posvátné rituální užívání ayahuasky v souladu s kulturně podmíněnými náboženskými a terapeutickými účely od obchodních a konzumních zájmů západní společnosti (Directorate Of Registration and Study of Contemporary Culture in Peru 2008).

V západním světě je otázka legality často nejasná. Čaj z liány obsahuje psychoaktivní látku DMT zakázanou v USA i ve většině evropských zemí. V Nizozemsku církev Santo Daime vyhrála soudní spor, což vedlo k formální legalizaci užívání ayahuasky v kontextu náboženských rituálů. Podobné soudní spory se vedou i v dalších zemích Evropy (Shanon 2002). Ayahuasca aktuálně představuje výzvu pro právní systém a zákonodárce, kteří usilují o balanci mezi trestnými zákony, veřejným zdravím a lidskými právy (Tupper 2008).

\section{Ayahuaskový šamanský turismus}

S přibývajícím povědomím o ayahuaskových šamanských rituálech vzrostl v posledních deseti letech počet cizinců především z Evropy a Severní Ameriky, kteří se účastní organizovaných výletů do Amazonie. Tyto výpravy mimo jiné zahrnují jedno nebo více ayahuaskových sezení se šamanem (Metzner 2006) a z domorodých posvátných tradic se tak rodí „spirituální byznys“. Francouzský lékař Dr. Mabit, zakladatel rehabilitačního a výzkumného centra pro drogově závislé v peruánském Tarapotu propojující principy tradiční amazonské medicíny a západní vědy, poznamenal, že západní svět má tendenci užívat tradiční prvky, vytržené z původního kontextu, konzumním způsobem (osobní sdělení 21. září 2013). Domorodí obyvatelé na př́liv cizinců reagují formou zakládání center, která nabízejí šamanské rituály s ayahuaskou pro cizince (Fotiou, 2010; Tupper, 2008, 2009). Dobkin de Rios (1994) tvrdí, že s rozvíjejícím se turismem a možností velkých výdělků může dojít k znesvěcení ritualizovaného užívání ayahuasky.

Na rozdíl od domorodých obyvatel Amazonie, kteří po tisíce let pili ayahuasku, aby se chránili prred nepráteli, předpovídali budoucnost nebo léčili své psychické či fyzické choroby, turisté tyto mystické či náboženské zážitky podstupují s touhou po seberealizaci a růstu. Často tím kompenzují něco, co v jejich životech a kultuře chybí, např. nedostatek společenské tradice a předávaných hodnot, nízké sebevědomí (Dobkin de Rios 1994) či nedostupnost alternativní léčby ve své zemi (Grunwell 1998; Metzner 2006). Winkelman (2005) ve své studii zjistil, že hlavní motivací turistů k užívání ayahuasky bylo spirituální uvědomění a navázání vztahů se spirituálnem, osobní rozvoj

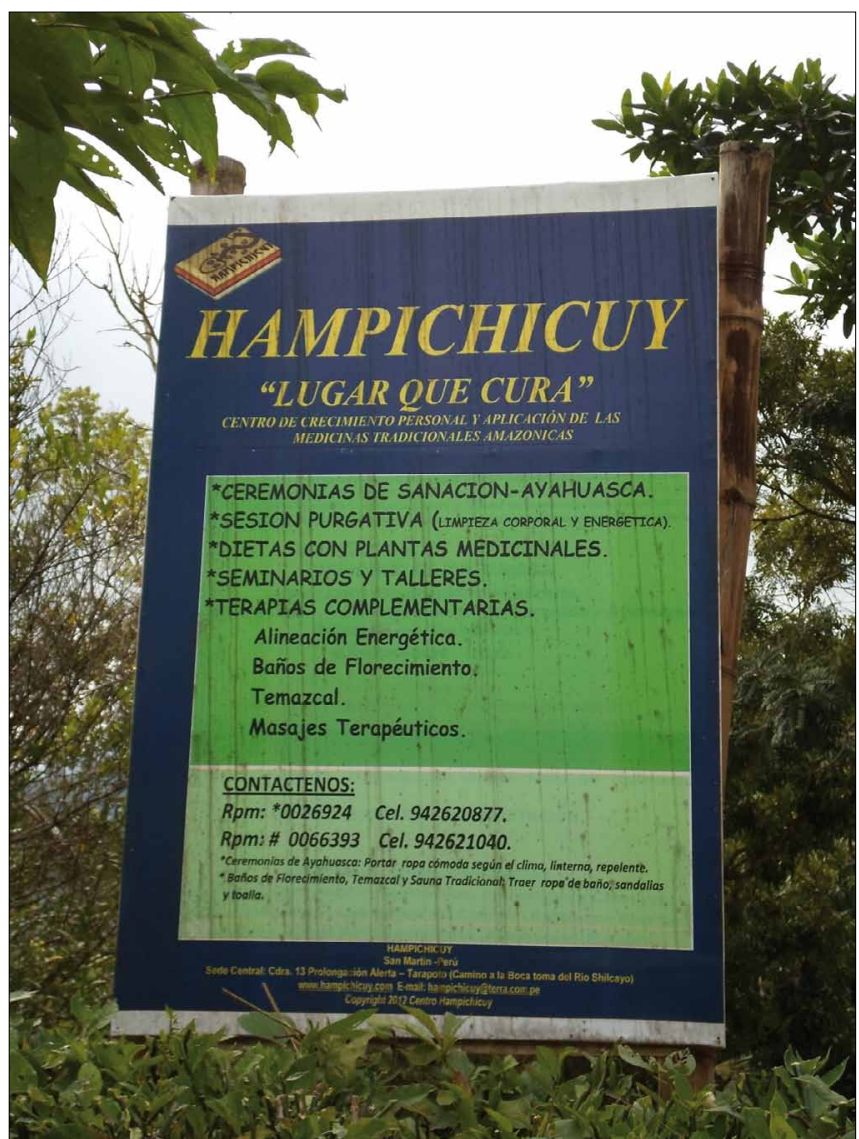

Obr. 3. Cedule nabízející sezení s ayahuaskou u města Tarapoto, Peru

a emocionální léčení. Někteří hledali životní směr, osobní vývoj či vyléčení závislosti na návykových látkách.

Zdá se, že lidé ze západu² prostřednictvím prožitků šamanských rituálů rozšiřují svůj systém víry a jdou za hranice konvenčního materialistického paradigmatu západní vědy. Opakovaně se vynořují témata týkající se obav o ochranu a integritu Země, ohrožené životní prostředí, živočišné druhy a domorodou kulturu. Rostoucí zájem o ayahuaskový šamanismus představuje světové hnutí za prrímé, empirické a spirituální spojení s prrírodním světem (Metzner 2006).

Účast turistů na ayahuaskových sezeních se zdá být unikátní ve smyslu zjevných benefitů, které $\mathrm{z}$ této zkušenosti mohou vytěžit. Je však důležité, aby bylo zajištěno bezpečné užívání ayahuasky (Grunwell 1998). Pro předejití negativním dopadům a zvýšení pozitivních účinků ayahuasky, adaptovali curanderos striktní opatření týkající se především dietních postupů a sexuálního omezení. Ayahuasca by měla být konzumována výhradně $\mathrm{v}$ rámci disciplinovaných rituálů v kontrolovaném prostředí (Mabit, \& Sieber 2006).

Pro osoby ze západu může být integrace tradičního modelu užívání ayahuasky obtížná a může vést ke zmatení a zkreslování dále předávaných informací (Grunwell 1998; Lewis 2008). Důraz by měl být kladen také na psychologickou resi-

2 Lidmi ze západu (Westernes) bývají často označováni lidé ze zemí Evropy a Severní Ameriky. 
lienci osob užívajících ayahuasku a možnost psychoterapeutického zpracování případné spirituální krize jako důsledku jejího užití (Lewis 2008).

Mabit poznamenává, že šamanismus má i svou stinnou stránku, když je praktikován nevhodným zpơsobem s neetickými záměry (osobní sdělení 21. záŕí 2013). Kavenská (2013) tvrdí, že důsledkem neprofesionálních praktik může být $\mathrm{v}$ lepším případě skeptický pohled na účinnost tradiční domorodé medicíny, v horším př́padě i závažné psychické problémy, jakými jsou zmatenost, deprese, psychotické stavy, aj. Tito lidé pak často vyhledávají jiné šamany, aby jim pomohli vzniklé potíže odstranit. Jsou popsány i př́pady, kdy se lidé „zbláznili“ nebo $\mathrm{v}$ důsledku podání toxických rostlin zemřeli.

Dobkin de Rios (2009) upozorňuje na tzv. léčitele, neošamany, kteří z tradičních ayahuaskových rituálů dělají byznys a turisty berou jako tučný zdroj prŕijmu. Mnoho $\mathrm{z}$ nich neprošlo dlouholetým šamanským výcvikem, který obnáší práci s rostlinami, učení se od zkušených curanderos a dobu strávenou $\mathrm{v}$ ústraní o samotě v džungli. Nemají tak potřebné znalosti, zkušenosti, kontrolu a osobnostní kvality, čímž riskují mentální i fyzické zdraví svých zákazníků. Mnozí léčitelé na příklad neberou v potaz zdravotní a duševní stav turistů, nemají znalosti o chemických interakcích látek, které jim podávají či nerespektují nutná dietních opatření.

Existují důkazy o tom, že při nedodržení přesných pravidel a osvědčených postupů může dojít $\mathrm{k}$ poškození osob užívajících ayahuasku. Dobkin de Rios $(2005,2009)$ upozorňuje na případy, kdy šamani přidali do odvaru $\mathrm{z}$ liány další toxické rostliny, např. květ halucinogenní rostliny toé (Brugmansia suaveolens) a způsobili turistům vážné psychické či zdravotní problémy, v některých př́ípadech i smrt.

Fotiou (2010) v rámci svého výzkumu o ayahuaskovém turismu v souvislosti s vlastními zkušenostmi a referencemi zúčastněných osob potvrzuje užívání šamanských schopností jak k léčení, tak i k záměrnému ubližování a poškozování druhých lidí (tzv. brujos).

Doposud jsme se zaměřovali především na ochranu cizinců, kteří podnikají daleké cesty do amazonských pralesů, aby se účastnili šamanských ayahuaskových rituálů. Otázkou je, jak na tento príliv turistů reagují místní lidé a jaký dopad to může mít na jejich život, kulturu a prostředí, ve kterém žijí. O vlivu ayahuskového turismu na domorodé obyvatele a ekonomiky těchto regionů se spekuluje, ale jisté je, že i nadále poroste (Tupper 2008). Metzner (2006) se zmiňuje o vlně kritiky vůči možným vykořistovatelským tendencím $\mathrm{v}$ souvislosti s pronikáním turistů do domorodých kultur. Grunwell (1998) ř́ká, že $s$ inflací turistů může dojít k ohrožení či vymizení zdrojů ayahuasky. Z opačného úhlu pohledu jsou turisté zdrojem př́ijmu do místních latinskoamerických ekonomik (Metzner 2006).

Ayahuaskový turismus je možné sledovat $s$ rostoucím množstvím internetových stránek a magazínů (např. Shaman's Drum) nabízejících „autentické šamanské rituály“ či návštěvy domorodých komunit (Grunwell 1998; Metzner 2006). $\mathrm{Z}$ analýzy webové stránky nabízející volnou účast na ayahuaskových šamanských ceremoniích (Holman 2011) vyplývá, že hlavní reklamní strategií je kombinace obchodního a spi- rituálního kontextu. Hlavní roli zde hrají zprostředkovatelé, kdežto domorodí lidé, kteří tuto zkušenost na místě poskytují, nejsou na internetu zmiňováni. Rozvíjí se mezinárodní obchod se spirituálem a tradičním domorodým mentálním dědictvím. Historický, sociální nebo tradiční kontext užívání rostlin $\mathrm{v}$ rámci ceremonií je nahrazován lákavým obchodním produktem ve formě „all - inclusive balíčkü“ dostupných pro kohokoliv kdo má dostatek času a peněz. Nabízí se otázka, kdo z ayahuaskového turismu těží nejvíce. Tupper (2009) tvrdí, že podle dostupných informací jsou to především prostředníci mezi klientem a šamanem, kteří si účtují vysoké poplatky za zprostředkování šamanských služeb.

Ayahuaskový turismus je kontroverzním tématem novodobé společnosti a je aktuální pro všechny země a kultury. Ayahuasca se proto stává fenoménem globálním, který vyžaduje realizaci dalších studií a veřejných diskuzí (Luna 2011). Z tohoto důvodu jsme se rozhodli provést mezinárodní studii a zjistit, co vede osoby z vyspělých moderních kultur do pralesů Jižní Ameriky a jaká jsou jejich očekávání a následné zkušenosti.

\section{METODY}

\section{Proces sběru dat}

Data byla sbírána ve třech fázích - v České republice (březen - květen 2013; září - ř́jen 2013) a v peruánské Amazonii (červen - srpen 2013) na místech známých jako centra ayahuaskového šamanského turismu (města Tarapoto a Iquitos). Výběr respondentů byl realizován metodou sněhové koule, záměrného - účelového výběru a metodou samosběru (Miovský 2006). Podmínkou zařazení do výzkumu bylo vycestování do zahraničí za účelem užívání ayahuasky a účast nejméně na jednom sezení s ayahuaskou. Respondenty jsme v Peru nejčastěji oslovovali na ulici, na turistických místech (restaurace, kavárny, hostely, atd.) a v centrech, která nabízela sezení $s$ ayahuaskou. Jako metoda sběru dat byly použity polostrukturované rozhovory, screeningové dotazníky a zúčastněné pozorování. Rozhovory v České republice byly vedeny v českém jazyce, v Peru v anglickém a španělském jazyce a byly nahrávány na diktafon, doplňovány ručními poznámkami a poté přepisovány. Účast ve výzkumu byla dobrovolná, účastníci byli informováni o anonymním nakládání s výzkumnými daty a mohli od výzkumu kdykoli odstoupit.

\section{Výběrový soubor}

Výzkumu se zúčastnilo 77 osob, z čehož bylo 47 mužů a 30 žen. 47 respondentů bylo české národnosti a 30 respondentů pocházelo z ostatních zemí Evropy, Jižní Ameriky a USA. U všech respondentů jsme zjištovali věk, rodinný status, dosažené vzdělání a počet absolvovaných sezení s ayahuaskou. Věkové rozmezí účastníků výzkumu bylo 20 až 78 let s průměrem 36,6 a směrodatnou odchylkou 12,3 roky. Minimální počet sezení s ayahuaskou bylo 1 a maximální 130, s průmě- 


\begin{tabular}{|c|c|c|c|c|c|c|c|}
\hline Věk & N & Vzdělání & N & Rodinný stav & N & Počet sezení & N \\
\hline$<19$ & 0 & ZŠ & 1 & Svobodný/á & 42 & 1 & 9 \\
\hline $20-29$ & 28 & SOU & 4 & Ženatý/vdaná & 21 & $2-5$ & 21 \\
\hline $30-39$ & 22 & SŠ & 30 & Rozvedený/á & 12 & $6-10$ & 16 \\
\hline $40-49$ & 13 & VŠ & 42 & Ovdov̌̌lý/á & 2 & $12-20$ & 12 \\
\hline $50-59$ & 11 & & & & & $21-30$ & 6 \\
\hline$>60$ & 3 & & & & & $31-50$ & 5 \\
\hline & & & & & & $>51$ & 8 \\
\hline
\end{tabular}

Tab. 1. Sociodemografické parametry výzkumného vzorku a počet sezení s ayahuaskou.

rem 17,7 a směrodatnou odchylkou 25,9. Více než polovina respondentů byli svobodní. Podrobnější popis výzkumného vzorku zobrazujie tabulka 1 výše.

\section{VÝSLEDKY}

Výsledky výzkumu vycházejí z analýzy rozhovorů, které probíhaly v České republice a peruánské Amazonii. Vypovídají o a) motivaci, b) prínosech a c) rizicích či negativních $z k u$ šenostech spojených s podniknutými cestami do zahraničí (nejčastěji do Peru) za účelem užívání ayahuasky. Nahrané rozhovory ve formě audio záznamů byly přepsány do textové podoby a následně analyzovány. Relevantní výpovědi vztahující se $\mathrm{k}$ položené otázce byly zaznamenány pod jednotlivé zkoumané oblasti do programu Microsoft Excel. Tyto výpovědi byly dále redukovány, zobecňovány a podle obsahu kódovány a seskupovány do větších významových jednotek (Hendl 2008). Vzniklo značné množství subkategorií pojmenovaných dle toho, co vyjadřovaly. $Z$ obsahově shodných subkategorií vznikly obecnější tematické kategorie, přičemž ty $s$ nejčetnějším zastoupením výpovědí respondentů zde uvádíme. Kategorie jsou pro lepší přehlednost znázorněny formou schémat a následně detailněji doplněny výroky respondentů. Ke každé kategorii je v závorce uvedena četnost respondentů, jejichž výpovědi se k dané kategorii vztahují, přičemž každý respondent odpovídal během rozhovoru na otevřené otázky a jeho výpovědi se mohou objevit ve více než jedné kategorii. Kategorie jsou pro ilustraci částečně doplněny doslovnými citacemi respondentů. Některé výpovědi se svou jedinečností od ostatních odlišovaly, nebyly tedy do kategorií zařazeny, avšak pro zajímavost je také uvádíme.

\section{A) MOTIVACE}

V této oblasti jsme zjištovali, co dotyčné osoby vedlo $\mathrm{k}$ tomu, že se rozhodly vydat se do Peru (či jinam do zahraničí) užívat ayahuasku. Zajímalo nás, jaké důvody předcházely samotnému rozhodnutí s tímto záměrem vycestovat a užít ayahuasku, co od této zkušenosti očekávaly, proč si vybraly právě tuto formu zkušenosti a daly ji přednost před běžnějšími a dostupnějšími formami realizace svých potřeb a prání.
Následující schéma (obr. 4) zobrazuje nejčastěji zmiňované důvody vycestování do zahraničí za účelem rituálního užití ayahuasky.

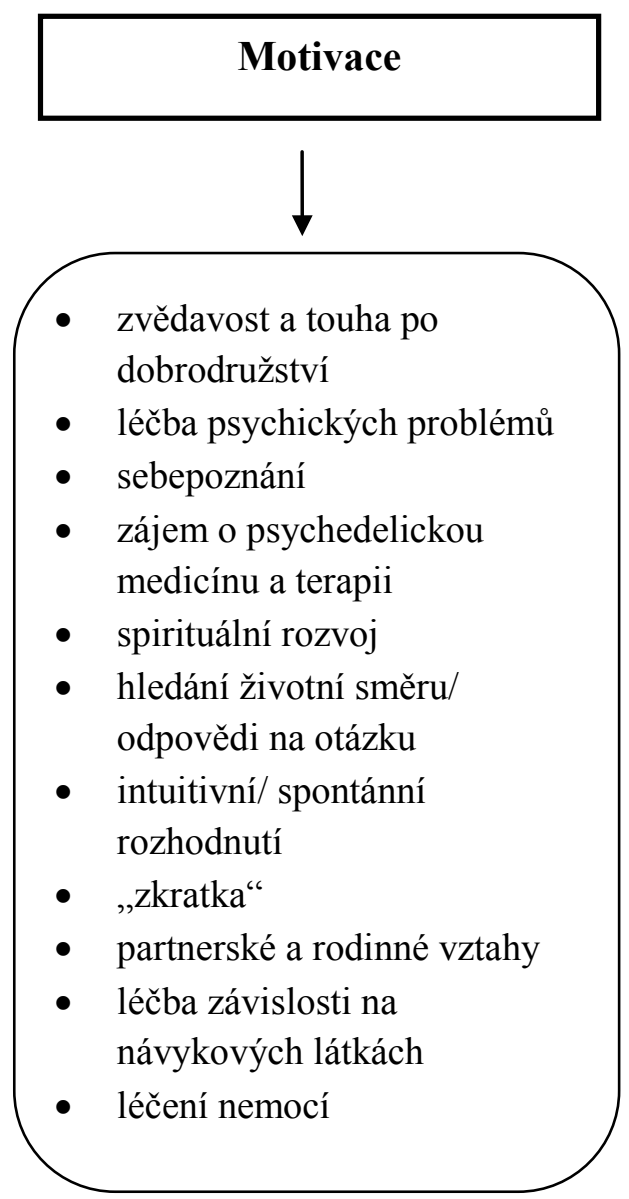

Obr. 4. Motivace pro vycestování do zahraničí za účelem užívání ayahuasky

Zvědavost/touha po dobrodružství (32): ve smyslu zvědavosti, touhy po dobrodružství, přání zažít neobvyklou exotickou dovolenou, zájem poznat cizí kulturu a prostředí, šamanské obřady, rituály nebo přání zjistit, zda se lze setkat se spirituálními bytostmi tak, jak vypovídali ostatní lidé. 
Léčba psychických problémů (26): hluboké deprese, sebevražedné tendence, vidina smrti a ayahuasca jako poslední možnost jak se zbavit úzkostných a depresivních stavů, tendence čelit a zbavovat se svých strachů, zbavit se panických atak, závislosti na ženách, nevěry, vyrovnání se se smrtí blízké osoby, znovuprožití a léčení životních traumat a zranění, potřeba ponořit se hluboko do sebe, do nevědomí- otevřít tzv. „černé skříňky“, které člověka limitují, osobní terapie, emoční oploštělost- nutnost prožít a uvolnit emoce, katarze- vnitřní duševní očista, zklidnění.

Sebepoznání (25): sebezkušenost, poznat lépe sám sebe, porozumět sobě, osobní vývoj a seberůst, prožitek nezávislosti, očištění duše od zbytečných „nánosů“ civilizace.

Zájem o psychedelickou medicínu a terapii (18): fascinace účinky ayahuasky, zájem o psychedelickou terapii, poznat práci s rostlinami, zájem učit se od rostlin, poznat a prozkoumat změněné stavy vědomí a získat náhled, který v běžném stavu vědomí nemáme, dotknout se něčeho nového, posun ve způsobu vnímání, transformace, vědecký zájem.

Spirituální rozvoj (17): touha poznat něco, co nás přesahuje, boha, hlouběji se propojit s životem a s bohem, spojení se $s$ vyšším vědomím, $s$ vyššími silami, $s$ energií, $s$ „paralelními světy“, hledání duchovní cesty, poznat nehmatatelný (vyšší) svět, najít smysl života, jít za hranice běžně vnímané reality, rozšírit si vědomí, poznat vesmír, přání zažít symbolickou smrt a znovu se narodit, zážitek sebe sama jako duchovní bytosti.

Hledání životního směru/odpovědi na otázku (14): ujasnit si životní směřování, životní křižovatka, potřeba posunu z místa, pochopit lépe život, změnit negativní pohled na život, zbavit se strachu žít život tak, jak chci, změnit nenaplňující nudný život a práci, potřeba hluboké změny životního stylu.

Intuitivní/spontánní rozhodnutí (11): vnitřní impulz či pocit „tam musím, tam bych měl jet“, intuitivní spontánní rozhodnutí, spontánní výlet. „To byl takový ten vnitřní impuls silný, jakože jo, tam chci, tam ted' potřebuju jit."

„Zkratka“ (7): ayahuasca jako „zkratka“, rychlejší cesta poznání, nutná „pecka do hlavy“, silnější, lepší, rychlejší cesta něco ucítit či poznat.

Partnerské a rodinné vztahy (5): pracovat na rodinných vztazích, zjistit, co dělám ve vztazích špatně a proč nefungují, zpracovat a pochopit složitý rozchod, čištění transgenerační historie, zpracovat smrt partnera, „... Nemohla jsem nic ucítit, nemèla jsem žádné emoce. Uvědomila jsem si, že musím změnit svůj život. Chtěla jsem porozumèt svým vztahưm a poznat, co dělám špatně, že v minulosti nikdy nefungovaly. “

Závislost na návykových látkách (4): touha zbavit se závislostí na marihuaně, tabáku a jiných drogách.
Léčení nemocí (3): alternativní medicína, léčba psychosomatických nemocí.

Ojediněle byla také zmíněna touha po spojení s př́rodou, nabídka ze strany kamaráda, nutnost odjet za hranice země, protože takovéto praktiky jsou v dané zemi nelegální, dovolená, očista těla, splnění dětského snu navštívit šamany v Amazonii, být s lidmi s nestandardními pohledy na svět nebo užití ayahuasky kvůli rodičům, kteří zkušenost zprostředkovali.

\section{Shrnutí motivace}

Z výpovědí respondentů vyplývá, že důvodů pro absolvování cest do Amazonie nebo jinam do zahraničí za účelem užití ayahuasky bylo několik. Zvědavost a touha po dobrodružství byla zmiňována téměř u poloviny respondentů, což poukazuje na dobrodružné založení těchto jedinců s tendencí vyhledávat nové a neobvyklé zkušenosti. Třetina respondentů zkušenost podstoupila s přáním zbavit se svých psychických problémů a poznat lépe sám sebe. Ayahuasca byla často považována za médium zprostředkovávající hlubokou sebezkušenost, osobní terapii a duševní očistu, což poukazuje na víru $\mathrm{v}$ její léčebné schopnosti. Tyto dvě nejčastěji uváděné motivace se v mnoha prrípadech doplňují.

Téměř čtvrtina respondentů mezi motivační činitele uvedla všeobecný zájem o psychedelickou medicínu a terapii a její případné využití $\mathrm{k}$ osobnímu rozvoji, léčení, vědeckému bádání a poznávání změněných stavů vědomí, které podle respondentů umožňují nazírat na realitu $\mathrm{z}$ nových úhlů pohledu. Čtvrtina respondentů uvedla jako primární motivaci touhu po duchovním rozvoji. Respondenti od zkušenosti očekávali také ujasnění si životního směřování či nalezení odpovědi na nezodpovězenou otázku. Považovali ayahuasku za prostředek vhledu nebo za cestu k uskutečnění života s pocitem naplnění. Rozhodnutí vycestovat a užít ayahuasku bylo často spontánní či intuitivní, doprovázené upozaděním racionálních úvah. Několik respondentů zkušenost s ayahuaskou považovalo za urychlení procesu poznání. Motivací bylo taktéž léčení osobních vztahů ve smyslu jejich pochopení a následné práci na jejich zlepšení. Objevily se i výpovědi o touze zbavit se závislosti na návykových látkách a prání vyléčit své somatické problémy.

Pokud bychom mohli identifikovat typického cestovatele za zkušenostmi s ayahuaskou, z hlediska motivace by jím byla osoba středního věku, která věnovala již mnoho let snaze léčit své duševní problémy a která nenašla uspokojivé řešení $\mathrm{v}$ rámci nabídky své společnosti, a tak se vydala hledat úzdravu touto alternativní cestou. Často se jedná o osoby s vysokou mírou otevřenosti vůči novým zkušenostem, zvídavé, duchovně založené.

\section{B) PŘÍNOSY}

Tato výzkumná oblast byla zaměřená na to, co dotyčná osoba ze zkušenosti vytěžila, $v$ čem pro ni byla zkušenost přínos- 
ná. Zajímalo nás také, jestli nyní vnímá věci jinak a zdali byl př́nos v souladu s očekáváním. Nejčastěji zmiňované prrínosy zachycuje následující schéma (obr. 5).

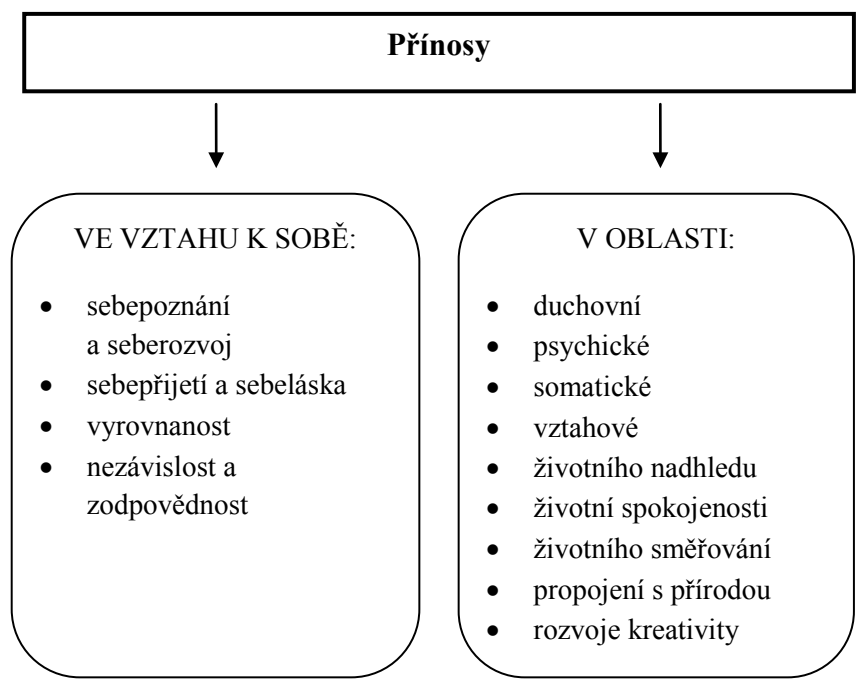

Obr. 5. Vnímané přínosy užívání ayahuasky.

Vztah k sobě (50):

- sebepoznání a seberozvoj - poznání sebe sama, porozumění sobě a přiblížení se sám sobě, komunikace a kontakt s tělem a emocemi, potvrzení vnímání sebe sama nebo nové vnímání sebe a svého těla, pocit komplexnosti, poznání svých předností a slabin, pochopení vlastních obran, integrace prožitých zranění svého „vnitřního dítěte“, urychlení procesu seberozvoje, rozvoje ženství, překonání sebe sama, vnitřní posílení a větší pečlivost

- $\quad$ sebeprrijetí a sebeláska- usmíření se sebou, vědomí, že jsem posvátný, péče o sebe a větší citlivost a vnímavost k sobě, „následování svého srdce“, větší přirozenost, sebedůvěra, nabytí celkového pocitu „lehkosti“

- vyrovnanost- ukotvení se ve svém středu

- nezávislost a zodpovědnost- za sebe a svůj život.

Duchovní rovina (34): duchovní cesta, rozvoj spirituality, (znovu)poznání boha, porozumění a víra $\mathrm{v}$ boha, zesílené vnímání mimo fyzickou realitu, potvrzení, že nás něco přesahuje, nové chápání světa, pochopení zákonitostí vesmíru, rostliny a bůh jako přátelé a průvodci, schopnost vidět auru kolem lidí a věcí, nalezení podstaty a smyslu života, uvědomění si materiálního nadbytku, nematerialistický přístup k životu, důvěra v život a respekt k životu, silnější intuice, vědomí jednoty, návrat do minulých životů a porozumění jejich vlivům v současnosti, pocit znovuzrození, prístup $\mathrm{k}$ informacím o svých předcích a duchovní „zátěži“ v rodině, „čištěni“ rodu, poznání síly modlitby, spojení s posvátnem, s bohem, uvědomění si nehmotné podstaty člověka.

Vztahová rovina (30): kvalitnější a lepší vztahy s druhými lidmi, usmíření se, větší citlivost, vnímavost, respekt a tolerance ve vztazích, porozumění příčinám neúspěchů $\mathrm{v}$ předchozích vztazích, propojení, porozumění, upřímnost, méně konfliktů ve vztazích, dobrovolnická činnost, nová přátelství, vděčnost, otevření svého srdce, naučení se opravdové bezpodmínečné lásce ke všemu v životě, změna pohledu na ženy, větší soucit, zdravá separace od matky, uvědomění, komu jsem v životě ublížil a kdo naopak mně, pocit, že jsem lepším člověkem.

Psychická rovina (28): vymizení depresí, úzkostí, suicidálních myšlenek, panických atak, uvolnění emocí, sebekontrola nad svým prožíváním a chováním, porozumění svému prožívání a chování, opuštění negativních vzorců chování, vyplavení a znovuprožití nevědomých vzpomínek, řešení konkrétních témat $\mathrm{z}$ osobní historie, vyléčení traumat, zbavení se svého tzv. vnitřního démona, zbavení se strachů (ze smrti, z budoucnosti, atd.), psychická očista, pocit jasné mysli, lepší percepce, uvolněnost, zbavení se psychických bloků v komunikaci.

Životní nadhled (26): uvědomění si podstatných věcí v životě, změna životních hodnot a priorit („kariéra a peníze nejsou tolik dưležité"), nezabývání se maličkostmi, lepší porozumění věcem v životě, snazší vnímání světa a lepší orientace v životě, lepší využití času, pokora, vážení si života.

Somatická rovina (19): zlepšení zdravotního stavu, pocit vyčištění těla („fyzický detox“), zmírnění bolestí, zhubnutí, cigaretová, alkoholová a drogová abstinence, zdravá výživa, péče o své tělo, láska ke svému tělu, sport.

Životní spokojenost (15): radost ze života, subjektivně prožívané štěstí, pocit osvobození, více lehkosti a „světla“v životě, více elánu a životní energie.

Životní směřování (11): posunutí se určitým směrem, našlápnutí do života, ujasnění si, co chci v životě dělat, profesního směřování.

Propojení s přírodou (5): propojení s „Matkou Zemi“, lepší vnímání prírody, tendence trávit více času v přírodě, větší pocit bezpečí $\mathrm{v}$ př́rírodě, více důvěry $\mathrm{k}$ př́rodě.

Kreativita (3): rozvoj vlastních tvořivých schopností v malování, hudbě, touha více tvořit.

Respondenti ojediněle jako přínosné uvedli setkání s odlišnou kulturou, přístup k novému učení, větší respekt k psychedelickým látkám či kontakt se zemřelou osobou během sezení $s$ ayahuaskou.

\section{Souhrn přínosů}

Výpovědi respondentů poukazují na široké spektrum možného využití ayahuasky v různých oblastech lidského života. Ayahuasca má podle výpovědí terapeutický potenciál na bio 
- psycho - socio - spirituální úrovni. Většina respondentů vnímala zkušenost $s$ ayahuaskou jako obohacující na rovině osobní. Pozitivně bylo hodnoceno přiblížení se sám sobě ve smyslu hlubšího sebepoznání doprovázeného efektivním procesem seberozvoje. Často zmiňované bylo sebepřijetí, které vedlo $k$ lepšímu vztahu sám $k$ sobě, větší přirozenosti a sebedůvěre. Dále pocit vnitřní vyrovnanosti, nezávislosti a zodpovědnosti za sebe a svůj život. Téměř polovina respondentů hovořila o rozvoji spirituality, nalezení boha či smyslu života, o celkovém zlepšení vztahů s druhými lidmi nebo o zbavení se psychických problémů a strachů, které negativně ovlivňovaly jejich životy. Třetina respondentů hodnotila pozitivně životní nadhled a změnu postojů a hodnot. Čtvrtina respondentů uvedla zlepšení zdravotního stavu a vyléčení závislosti na návykových látkách. Pětina účastníků výzkumu spojuje zkušenost s nabytím životní spokojenosti. Jako př́nosné bylo také zmíněno ujasnění si životního směřování, propojení $\mathrm{s}$ přírodou a rozvoj kreativity.

\section{C) RIZIKA A NEGATIVNÍ ZKUŠENOSTI}

Na základě předchozích záznamů o poškození osob v souvislosti s nedbalým podáním ayahuasky a nekalými praktikami některých curanderos jsme se ve výzkumu zaměřili také na možná rizika a výskyt negativních zkušeností účastníků ayahuaskových sezení. Zajímalo nás, jestli dotyčná osoba nebo někdo jiný ze skupiny zažil nějakou negativní zkušenost, co teoreticky hrozilo a jaké byly možnosti řešení, pokud se ohrožující situace vyskytla.

Ačkoli téměř všichni respondenti uvedli, že sezení s ayahuaskou často provázely nepř́ijemné prožitky různých forem a intenzity, od nepř́ijemné chuti ayahuasky při jejím požití, nepř́ijemných tělesných reakcí doprovázených pocitem nevolnosti, zvracením, průjmy nebo naopak neschopností se vyzvracet, až po nesnesitelné vize a strach ze smrti, $\mathrm{z}$ temnoty tzv. „setkání se s démonem“, z délky sezení, „že to nevydržím“, či z předávkování, nebyly tyto prožitky následně respondenty hodnoceny jako nežádoucí, nýbrž jako smysluplné s kladným dopadem na jejich život. $Z$ tohoto důvodu je do kategorie rizik nezařazujeme. Podle výpovědí vedly tyto prožitky $\mathrm{k}$ nejrůznějším vhledům, pocitům úlevy, očištění se, apod. (viz přínosy), což bylo později respondenty vysoce ceněno. Výjimku tvoří jedna respondentka, která zkušenost s ayahuaskou hodnotila jako traumatizující. Následující schéma (obr. 6) udává nejčastěji zmiňovaná rizika.

Nedůvěra $v$ šamana či negativní pocity ze šamana (15): šaman byl během ceremonie unavený, usnul nebo byl opilý, př́tomnost jazykové bariéry mezi šamanem a účastníky ayahuaskových sezení, která znesnadňovala vzájemnou komunikaci, šaman vnímán jako businessman a ceny za jednotlivá sezení s ayahuaskou jako nadsazené. Zmíněn byl také pocit, že se šaman snažil svést jednu $\mathrm{z}$ účastnic, sex se šamanem a následné deprese provázené pocitem „že je na mě napojený a vysává ze mě energii“. Nekontrolované ceremonie, „kamarádka musela během těžkého stavu s ayahuaskou budit šama-

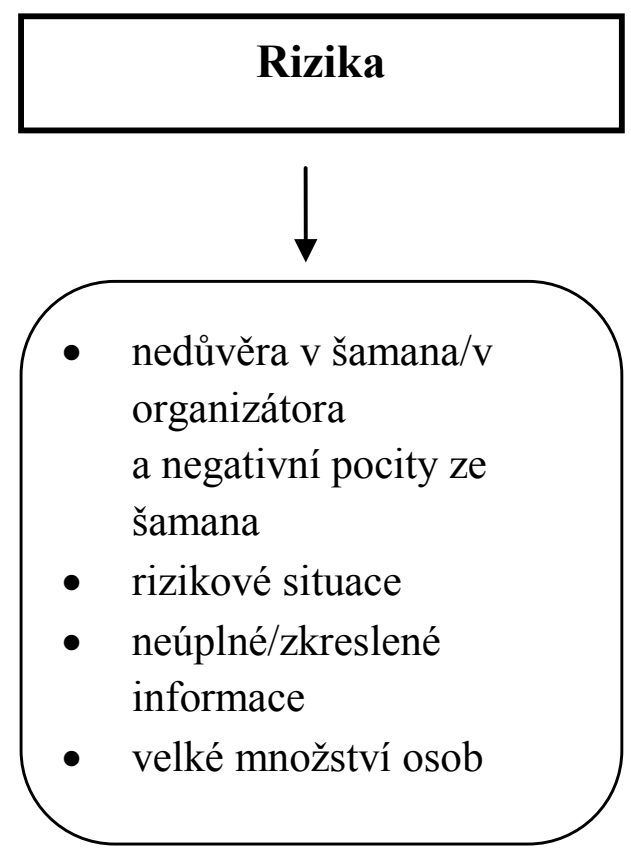

Obr. 6. Vnímaná rizika a negativní zkušenosti.

na, aby jí pomohl“. Pocit, jako by to pro šamany byla „jen další ceremonie“- „mohl se do toho víc vložit“. Strach jestli šaman nalije ayahuasku nebo něco jiného, šaman o účastnících neměl dostatek informací, protože to zařizoval prostředník, šaman se snažil vnutit účastníkům svou víru, účastník dopředu platil za 8 sezení $s$ ayahuaskou stejnou částku jako jiný účastník, který jich měl 18. Počáteční pocit, že to nefunguje, že jde o podvod (do chvíle, než si dal další šálek ayahuasky), šaman nebyl přítomen u člověka, který jeho pomoc potřeboval.

Ohrožující situace (10): hrozba přepadení domorodými kmeny, domorodí obyvatelé stř́ileli do vzduchu, konflikt s domorodými obyvateli, španělští přistěhovalci nás chtěli zabít, strach $\mathrm{z}$ džungle, $\mathrm{z}$ hmyzu, hadů a pavouků, (had u tamba př́bytku - v pralese), špína, vlhko, zima a nepohodlí u šamana $\mathrm{v}$ maloce ${ }^{3}$ během sezení $\mathrm{s}$ ayahuaskou, rychlý konec sezení $\mathrm{s}$ ayahuaskou, „byl jsem ve změněném stavu vědomí ještě asi po hodině od skončení ceremonie“, panika v osamění během doznívání ayahuasky po ukončeném sezení. Jako rizikové bylo také zmiňováno kombinování ayahuasky a halucinogenního kaktusu San Pedro, nekontrolované odchody účastníků do pralesa během ceremonie a sezení s ayahuaskou na vysokém útesu.

Nedůvěra v organizátora (4): nedůvěra $\mathrm{v}$ českého/zahraničního průvodce během výpravy.

3 Maloca je místnost většinou kruhovitého půdorysu tradičně užívaná pro sezení s ayahuaskou. 
Zkreslené informace (3): na sezeních $s$ ayahuaskou nebyl př́tomen člověk, který tam měl být, $\mathrm{v}$ centru u šamana se nevyskytovalo to, co bylo napsáno na internetu. "Pưvodnè jsem nevěděla, že výprava bude s ayahuaskou".

Mnoho osob na ayahuaskových sezeních (3): sezení s ayahuaskou za př́tomnosti velkého množství osob bylo nepř́ijemné, zdlouhavé, šaman měl na ceremonii 30 účastníků a neměl situaci pod kontrolou.

Ojediněle respondenti zmínili problémy s dopravou- „upadlo kolo u autobusu“, „ukradli nám lod ", krádež či ztrátu osobních věcí (mobilní telefon, fotoaparát), náročnou integraci zkušenosti a nápor na psychiku, „pak je na to člověk sám“, upřímnost $\mathrm{k}$ „prátelům“ posléze zkomplikovala vztahy a vedla $\mathrm{k}$ zániku některých prátelství. Problémy s druhými lidmi během expedice, $12-14$ hodinová sezení s ayahuaskou, která vedla k úplnému vyčerpání. Nedodržení dietních opatření- „, obědu jsem snědla chilli omáčku, což vyvolalo nepř́ijemné pocity během sezení s ayahuaskou". Zmíněn byl také strach ze vzniku závislosti na ayahuasce, neuvedení pravdivých informací $\mathrm{v}$ anamnestickém dotazníku ze strany účastníka (užívané léky, nemoci atd.), názor, že Evropané mění indiánskou kulturu a džungli, strachy před různými druhy ceremonií (např. chilli ceremonie), odjezd účastníka výpravy po prvním sezení s ayahuaskou doprovázený pocitem omnipotence.

\section{Souhrn rizik}

Přestože většina respondentů považovala užívání ayahuasky za bezpečné, někteří respondenti zmínili určitá rizika a negativní zkušenosti, kterým museli čelit. Největší důraz byl kladen na výbèr důvěryhodného zkušeného šamana, který je schopen zajistit bezpečný průběh užívání ayahuasky. „Vždycky $u$ těch sezení je di̊ležitá síla toho šamana. Protože ten šaman s tebou po celou tu dobu komunikuje, on je na tebe napojený, na všechny".,Já si nedovedu predstavit, co by se stalo, kdyby ti šamani nebyli úplnè seriozní a dali mi jen napit tý ayahuasky, a stalo se, že by mi vytáhly duši $z$ tèla a nechali by mi ji bejt. “. Nedůvěra v šamana bývá provázená strachem ze ztráty kontroly, ze smrti, z propuknutí psychického onemocnění, ze znásilnění, apod. Pro bezpečné užívání ayahuasky je podle zkušeností respondentů doporučeno dodržovat mj. dietní opatření a sexuální abstinenci. Někteří respondenti uvedli, že si šamani/zprostředkovatelé za sezení s ayahuaskou či jeho zprostředkování účtují vysoké částky. Několik respondentů uvedlo, že jim nebyl znám přesný účel a průběh plánované výpravy, na místě nebylo to, co bylo předem slibováno nebo že byli během této zkušenosti vystaveni rizikovým situacím. Podle některých výpovědí může být pro osoby ze západu obtížné zkušenost $s$ ayahuaskou následně zpracovat a integrovat do běžného života.

\section{DISKUZE}

Výsledky výzkumu zahrnují výpovědi 77 osob, které mají zkušenost $s$ užitím ayahuasky a podávají přehled o motivaci pro vycestování do zahraničí za účelem užití ayahuasky, vnímaných př́nosech a rizicích. Hlavní motivací byla především zvědavost, touha po sebepoznání a léčení psychických a emočních problémů. Dále pak zájem o psychedelickou medicínu, spirituální rozvoj a hledání životního směru. Často šlo o intuitivní či spontánní rozhodnutí, vnímání ayahuasky jakožto „zkratky“, prostředku pro řešení partnerských a rodinných vztahủ, závislosti na návykových látkách a léčení nemocí. Tato zjištění se do značné míry shodujís dříve provedenou studií Winkelmana (2005) jejíž výsledky odhalily, že hlavní motivací osob pro užití ayahuasky bylo hledání spirituálních vztahů zahrnujících kontakt s posvátnou prírodou, $\mathrm{s}$ bohem či se spirituálními entitami a rostlinami, osobní spirituální rozvoj, emocionální léčení, hledání životního směru, osobní vývoj či léčení závislosti na návykových látkách. Bylo by zajímavé provést rozhovor před a po zkušenosti, nebot zmíněná motivace mohla být prožitou zkušeností do značné míry ovlivněna.

Zpětné hodnocení zkušenosti se $\mathrm{z}$ velké části shoduje s očekáváním respondentů. Za př́nosy $\mathrm{v}$ souvislosti s užitím ayahuasky byla nejčastěji považována celková změna ve vztahu k sobě, která zahrnuje sebepoznání a seberozvoj, sebepřijetí a sebelásku, vyrovnanost, nezávislost a zodpovědnost za svůj život. Užívání ayahuasky vedlo $\mathrm{k}$ prohloubení spirituality, $\mathrm{k}$ sebepřesahu, $\mathrm{k}$ nalezení smyslu života či ke změně životních hodnot. Respondenti často hovořili o emoční, psychické a fyzické očistě a lepších vztazích s druhými lidmi. Byl také zmiňován životní nadhled, spokojenost a ujasnění si životního směřování. Tato zjištění $\mathrm{z}$ velké části odpovídají výsledkủm dříve provedených studií (Barbosa, Giglio, \& Dalgalarrondo 2005; Winkelman 2005; Trichter 2006-7; Barbosa, Cazorla, Giglio, \& Strassman 2009; Schmid, Jungaberle \& Verres 2010). Ačkoliv se může zdát, že je ayahuasca cenným nástrojem psychického rozvoje a léčby, je nutné vzít $\mathrm{v}$ úvahu také některá fakta, která mohla výsledky studie zkreslit. Tím zásadním je subjektivní charakter výpovědí respondentů. Je téměř nemožné ověřit, zdali zmíněné př́ńnosy odpovídají skutečnosti. Výpovědi mohou být do jisté míry ovlivněny očekáváním, vnitřním přesvědčením respondenta nebo zkresleny jinými individuálními faktory. I přesto považujeme za prínosné, že zkušenost $s$ ayahuaskou přinesla změny ve vnímání sebe i okolí. Rozhodnutí vydat se za zkušeností s ayahuaskou do Amazonie bylo často motivováno subjektivním pocitem psychické nepohody. Pozitivním efektem je tedy již i samotná proměna tohoto subjektivního pocitu. Většinu psychických fenoménů (zejména těch, které souvisejí s prožíváním) navíc všeobecně nelze zjištovat jinak než za pomoci metody introspekce, která je vždy subjektivní a neverifikovatelná. Poslední poznámkou k tomuto bodu je naše úvaha o tom, že pro pocit duševní spokojenosti není důležité, co si o našem vnitřním psychickém světě myslí druzí, ale právě to, jak jej my sami subjektivně vnímáme a zažíváme. 
Další faktor, který mohl vést ke zkreslení výsledků, je uplynulá doba od poslední zkušenosti s ayahuaskou. Některé rozhovory byly vedené s velmi krátkým časovým odstupem (druhý den po užití ayahuasky), jiné s odstupem týdnů, měsíců či let. Většina respondentů považovala zkušenost za bezpečnou. Bezpečné užívání ayahuasky bez známek návykovosti potvrdily také předchozí studie (Gable 2007; Fábregas et al. 2010; Bouso et al. 2012), z nichž některé prokázaly zlepšení fyzického zdraví osob v souvislosti s užíváním ayahuasky (Schmid, Jungaberle, \& Verres 2010) či vyléčení drogových závislostí (Mabit, \& Sieber 2006; McKenna 2004), což se shoduje s výpověd’mi respondentů $\mathrm{v}$ naší studii. Jsme si vědomi limitů vyplývajících $\mathrm{z}$ obtížného přístupu k osobám, kterým zkušenost $\mathrm{s}$ ayahuaskou mohla způsobit újmu, a které se $\mathrm{z}$ osobních důvodů mohou vyhýbat studiím jako je tato.

Ačkoli většina respondentů považovala prožitky během sezení s ayahuaskou za náročné, byly tyto prožitky později hodnoceny kladně, nebot' vedly mj. k vhledům, úlevě a celkovému pocitu očisty a zkvalitnění života. $Z$ tohoto důvodu jsme je mezi rizika nezařadili.

Z negativních zkušeností byla nejčastěji uváděna nedůvěra v šamana či negativní pocity ze šamana, což s sebou podle výpovědí nese riziko potenciálního poškození účastníků ayahuaskových rituálů. $Z$ výpovědí vyplývá, že je nezbytné mít dostatek informací o člověku, který ayahuaskové sezení nabízí, zjistit si reference od lidí, kteří jej znají nebo s ním v minulosti sezení s ayahuaskou absolvovali, a tím predejít vystavení se nebezpečné situaci a $\mathrm{z}$ ní plynoucích následků.

Někteří respondenti zmínili ohrožující situace, kterým museli v průběhu své cesty nebo během užíání ayahuasky čelit. Domníváme se, že zprostředkovatel/šaman by měl mít povinnost účastníkům zajistit bezpečí v průběhu celé výpravy včetně užívání ayahuasky a poskytnout těmto osobám informace týkající se možných negativních důsledků vyplývajících z nedodržení doporučení pro její bezpečné užívání. Dủležité je podávat ayahuasku na bezpečných místech neohrožujících zdraví či život jedince, organizovat sezení s přiměřeným množstvím účastníků, aby měl situaci neustále pod kontrolou a zajistit účastníkům bezpečí i po skončení ceremonie. Pokud je výprava organizována zprostředkovatelem či průvodcem, který je po dobu expedice př́tomný, měla by tato osoba zajistit pohyb $\mathrm{v}$ bezpečných oblastech a zodpovídat za průběh celé výpravy. Šaman/zprostředkovatel by měl znát zdravotní a psychický stav jedince, který by mohl být kontraindikací k užívání ayahuasky a následně ohrozit fyzické či duševní zdraví jedince. Někteří respondenti uvedli, že nedůvěřovali organizátorovi výpravy nebo že jim zprostředkovatel/šaman poskytnul neúplné či zkreslené informace. Účastník ayahaskových rituálů by měl mít právo na pravdivé zodpovězení všech otázek týkajících se cesty i samotného užívání ayahuasky. Podle některých výpovědí může být pro osoby ze západu obtížné zkušenost $s$ ayahuaskou následně zpracovat a integrovat. Úspěšná integrace je důležitá pro eliminaci pocitů zmatenosti, odosobnění, v extrémních případech propuknutí psychických obtiží, jako např. deprese, aj. $\mathrm{O}$ důležité roli integrace zkušenosti se zmiňují také někteří autoři (Grunwell
1998; Lewis 2008, Luna 2010, in Strassman, Wojtowicz, Luna, \& Frecska 2010).

Pokud se člověk rozhodne zkušenost s ayahuaskou podstoupit, měl by brát výše zmíněná rizika v úvahu. Většina respondentů uvedla některá doporučení, kterých se jim ze strany šamana či organizátora dostalo. Vztahují se především k dodržování dietních opatření a sexuální abstinence před, v průběhu a po užívání ayahuasky. $\mathrm{O}$ důležitosti dodržování přísných pravidel a dietních opatření informovali také mnozí autoři (Grunwell 1998; Mabit 2002; Dobkin de Rios, \& Grob 2005; Mabit, \& Sieber 2006; Dobkin de Rios 2009; Kavenská 2013). Považujeme za důležité šírit tyto informace mezi osoby, které zkušenost s ayahuaskou vyhledávají, aby se předešlo jejich potenciálnímu poškození nedbalým podáním ayahuasky nebo jejich zneužití ze strany šamana či zprostředkovatele.

\section{ZÁVĚR}

Celkově lze zhodnotit, že ayahuasca má podle výpovědí respondentů terapeutický potenciál na bio - psycho - socio - spirituální úrovni. Lidé, kteří mají zkušenost s rituálním užíváním ayahuasky, a kteří se zúčastnili našeho výzkumu, se považují za osoby vyrovnané, spokojené, nezávislé a zodpovědné za svůj život, s vysokým stupněm sebepoznání, životním nadhledem, duchovním přesahem a prosociálními empatickými sklony. Výpovědi respondentů poukazují na spirituální přesah cest do Amazonie s výraznými pozitivními změnami v prožívání i v chování, ve vztahu k sobě, k druhým lidem, $\mathrm{k}$ okolí a k životu obecně. Lze tedy usuzovat, že při dodržení pravidel spojených s užíváním ayahuasky, je ritualizované užívání pod vedením zkušeného důvěryhodného kurandera bezpečné a má pozitivní dopad na život jedince. Zdá se, že s rostoucí globalizací a relativně snadnému prrístupu k informacím budou lidé ze západu i nadále stále častěji vyhledávat různé možnosti a způsoby vedoucí k užití ayahuasky. Považujeme proto za přínosné provést další studie zaměřené na toto téma.

\section{LITERATURA}

Barbosa P. C. R, Giglio, J. S, \& Dalgalarrondo, P. (2005): Altered States of Consciousness and Short-Term Psychological After-Effects Induced by the First Time Ritual Use of Ayahuasca in an Urban Context in Brazil. Journal of Psychoactive Drugs 37 (2), 193-201.

Barbosa, P. C. R., Cazorla, I. M., Giglio, J. S., \& Strassman, R. (2009): A Six-Month Prospective Evaluation of Personality Traits, Psychiatric Symptoms and Quality of Life in Ayahuasca-Naive Subjects. Journal of Psychoactive Drugs, 41 (3), 205-212.

Beyer, S. V. (2009). Singing to the Plants: A Guide to Mestizo Shamanism in the Upper Amazon. Albuquerque: University of New Mexico Press.

Bouso, J. C., Gonzáles, D., Fondevila, S., Cutchet, M., Fernández, X, Barbosa, P. C., \& Riba, J. (2012): Personality, Psychopathology, Life Attitudes and Neuropsychological Performance among Ritual Users of Ayahuasca: A Longitudinal Study. PLoS ONE, 7 (8): e42421. doi:10.1371/journal. pone.0042421.

de Araujo, B., Ribeiro S., Cecchi G., A., Carvalho F. M., Sanchez T. A., Pinto J. P., .. \& Santos A. C. (2012):Seeing With the Eyes Shut: Neural Basis of Enhanced Imagery Following Ayahuasca Ingestion. Human Brain Mapping, 33 (11), 2550-2560. 
Directorate Of Registration and Study of Contemporary Culture in Peru. (2008): Designation as Cultural Patrimony of the Nation Extended to the Knowledge and Traditional Uses of Ayahuasca as Practided by Native Amazon Communities. National Directorial Resolution Number 836/ INC. (online). http://www.bialabate.net/wp-content/uploads/2008/08/ declaration_ayahuasca_patrimony_peru_20081.pdf

Dobkin de Rios, M. (1994): Drug Tourism in the Amazon: Why Westerners Are Desperate to Find the Vanishing Primate. Omni, 16, (4), 6-6.

Dobkin de Rios, M. (2005): Interview with Guillermo Arrévalo, a Shipibo Urban Shaman, by Roger Rumrrill. Journal of Psychoactive Drugs, 37 (2), 203-207.

Dobkin de Rios, M., \& Grob, Ch. (2005): Editors' Introduction: Ayahausca Use in Cross-Cultural Perspective. Journal of Psychoactive Drugs, 37 (2), 119-121.

Dobkin de Rios, M. (2009): The Psychodelic Journey of Marlene Dobkin de Rios: 45 years With Shamans, Ayahuasqueros, and Ethnobotanists. Vermont: Park Street Press.

Callaway, J. C., Raymon, L. P., Hearn W. L., McKenna D. J., Grob, Ch. S., Brito, G. S., et al. (1996): Quantitaion of N,N-Dimethyltryptamine and Harmala Alkaloids in Human Plasma after Oral Dosing with Ayahuasca. Journal of Analytical Toxikology, 20, 492-497.

Fábregas, J. M., González, D., Fondevila, S. Cutcheta, M. Fernándezc, X., Barbosad, P. C. R., Alcázar-Córcolese, M. Á. , Barbanoj, M. J., Ribaf, J., \& Bousof, J.C. (2010): Assessment of Addiction Severity Among Ritual Users of Ayahuasca. Drug and Alcohol Dependence 111, 257-261.

Fotiou, E. (2010): Encounters with Sorcery: An Ethnographers's Accoung. Anthropology and Humanism, 35 (2), 192-203.

Frecska E., Móré C. E., Vargha A., \& Luna L. E. (2012): Enhancement of Creative Expression and Entoptic Phenomena as After-Effects of Repeated Ayahuasca Ceremonies. Journal of Psychoactive Drugs. 44, (3), 191-199.

Gable, R. S. (2007): Risk Assessment of Ritual Use of Oral Dimethyltryptamine (DMT) and Harmala Alkaloids. Adiction, 102, 24-34.

Grunwell, J. N. (1998): Ayahuasca Tourism in South America. Multidisciplinary Association for Psychedelic Studies 8 (3), 59-62.

Heaven, R., \& Charing, H. G. (2006): Traditional Techniques for Healing the Soul. Vermont:One Park Street.

Hendl, J. (2008): Kvalitativní výzkum. Základní teorie, metody a aplikace. Praha: Portál.

Holman, Ch. (2011): Surfing for the Shaman: Analyzing an Ayahuasca Website, Annals of Tourism Research, 38 (1), 90-109.

Kavenská, V. (2013): Tradiční medicína Jižní Ameriky a její využití v psychoterapii. Olomouc: Univerzita Palackého v Olomouci.

Krippner, S., \& Sulla, J. (2000): Identifying Spiritual Content in Reports From Ayahuasca Sessions. The International Journal of Transpersonal Studies, 19, 59-76.

Labate, B. C., \& Goldstein, I. (2009): Ayahuasca- From Dangerous Drug to National Heritage: An Interview with Antonio A. Arantes. International Journal of Transpersonal Studies, 28, 53-64.

Lewis, S. E. (2008): Ayahuasca and Spiritual Crisis: Liminality as Space for Personal Growth. Anthropology of Consciousness, 19 (2), 109-133.

Luna, L. E. (2002): Vegetalismo. Šamanismus mezi mestickým obyvatelstvem peruánské Amazonie. Praha: DharmaGaia.

Luna, L. E. (2011): Indigenous and Mestizo Use of Ayahuasca. An Overview. In: Dos Santos, R.G. (Ed.). The Ethnopharmacology of Ayahuasca. Kerala: Transworld Research Network.

Mabit, J., Campos, J., \& Arce, J. (1992): Consideraciones acerca del brebaje ayahuasca y perspectivas terapéuticas [Considerations about the brew ayahuasca and therapeutic perspectives], Revista de Neuro-Psiquiatría, 2, 118-131.

Mabit, J. Giove, R., \& Vega, J. (1996): Takiwasi: The Use of Amazonian Shamanism to Rehabilitate Drug Addicts. Yearbook of Cross-Cultural Medicine and Psychotherapy, International Institute of Cross-Cultural Therapy Research, 257-285.

Mabit, J. (2002): Blending Traditions: Using Indigenous Medicinal Knowledge to Treat Drug Addiction. Multidisciplinary Association for Psychedelic Studies, 12 (2), 25-32.

Mabit, J., \& Sieber, C. (2006): The Evolution of a Pilot Program Utilizing Ayahuasca in the Treatment of Drug Addictions. Shaman's Drum Journal, $73,23-31$.
McKenna, D. J. (2004): Clinical Investigations of the Therapeutic Potential of Ayahuasca: Rationale and Regulatory Challenges. Pharmacology \& Therapeutics. 102, 111-129.

McKenna, D. J., Towers, G. H. N., \& Abbott, F. (1984): Monoamine Oxidase Inhibitors in South American Hallucinogenic Plants: Tryptamine and beta-Carboline Constituents of Ayahuasca. Journal of Ethnopharmaco$\log y, 10,195-223$.

Metzner, R. (2006): Sacred Vine of Spirits: Ayahuasca. Rochester: Park Street Press.

Miovský, M. (2006): Kvalitativní přistup a metody v psychologickém výzkumu. Praha: Grada Publishing.

Riba, J., Rodrígues-Fornells, A., Urbano, G., Morte, A., Antonijoan, R., Monteiro, M., et al. (2001): Subjective Effect and Tolerability of the South American Psychoactive Beverege Ayahuasca in Healthy Volunteers. Psychopharmacology, 154, 85-95.

Riba, J., Romero, S., Grasa, E., Mena, E., Carrió, I., \& Barbanoj, M. J. (2006): Increased Frontal and Paralimbic Activation Following Ayahuasca, the Pan-amazonian Inebriant. Psychopharmacology, 186, 93-98.

Shanon, B. (2002): The Antipodes of the Mind: Charting the Phenomenology of the Ayahuasca Experience. Oxford: Oxford University Press.

Schmid, J. T., Jungaberle. H., \& Verres, R. (2010): Subjective Theories about (Self-)Treatment with Ayahuasca. Anthropology of Consciousness, 21 (2), 188-204.

Strassman, R., Wojtowicz, S., Luna, L. E., \& Frecska, E. (2010): Vnitřní cesty do vnějšího vesmíru. Praha: dybbuk.

Trichter, S. (2006-7): Ayahuasca and Spirituality: Empirical Research on Experiencing the Divine. Multidisciplinary Association for Psychedelic Studies, 17 (3), 23.

Tupper K. W. (2008): The Globalization of Ayahuasca: Harm Reduction or Benefit Maximization? International Journal of Drug Policy, 19 (4), 297 303

Tupper, K. W. (2009): Ayahuasca Healing beyond the Amazon: the Globalization of a Traditional Indigenous Entheogenic Practice. Oxford: Wiley -Blackwell, 9 (1),117-136.

Winkelman, M. (2001): Alternative and Traditional Medicine Approaches for Substance Abuse Programs: A Shamanic Perspective. International Journal of Drug Policy. 12 (4), 337-351.

Winkelman, M. (2005): Drug Tourism or Spiritual Healing? Ayahuasca Seekers in Amazonia. Journal of Psychoactive Drugs, 37 (2), 209-218.

\section{AUTORKY}

Veronika Kavenská (20. 9. 1983, Havlíčkův Brod), psycholožka, přednášející na Katedře psychologie Univerzity Palackého v Olomouci. Již více než sedm let se odborně zajímá o téma psychologického využití tradiční amazonské medicíny (šamanismus, curanderismo). Za tímto účelem navštívila několikrát peruánskou Amazonii a absolvovala zde dvě odborné stáže, po dobu dvou a deseti měsíců. Je frekventantkou psychoterapeutického výcviku analytické psychologie C. G. Junga.

Kontakt: PhDr. Veronika Kavenská, Ph.D., Katedra psychologie, Filozofická fakulta Univerzity Palackého v Olomouci, Vodární 6, Olomouc, 779 00, Veronika.Kavenska@gmail.com

Hana Simonová (23. 12. 1989, Svitavy), studentka magisterského studia jednooborové psychologie na FF UP v Olomouci, absolvovala půl roční studijní pobyt na University of Groningen v Nizozemském království. Zajímá se o využití tradiční amazonské medicíny, šamanismu, transpersonální psychologie a expresivních prrístupů v psychoterapii. Během studia spolupracovala na dvou výzkumných projektech financovaných ze zdrojů studentské grantové soutěže IGA. Kontakt: Hana Simonová, Katedra psychologie, Filozofická fakulta Univerzity Palackého v Olomouci, Vodární 6, Olomouc, 779 00, h.simonova@email.cz 
